\title{
EVALUASI HASIL PELATIHAN DI PUSDIKLAT TENAGA TEKNIS PENDIDIKAN DAN KEAGAMAAN
}

\author{
Ratna Prilianti ${ }^{1}, \mathrm{Ma}^{\prime}$ arif ${ }^{2}$, Gunarno ${ }^{3}$ \\ 'Balai Diklat Keagamaan Semarang, \\ ${ }^{2}$ Balai Diklat Keagamaan Makassar, \\ ${ }^{3}$ Balai Diklat Keagamaan Medan \\ ${ }^{1}$ ratna.prilianti@gmail.com; 2ariefam1975@gmail.com; ${ }^{3}$ narnowibdkmdn@gmail.com
}

https://doi.org/10.36052/andragogi.v8i1.112

Diterima: 01 April 2020 | Disetujui: 08 Juni 2020 | Dipublikasikan: 30 Juni 2020

\begin{abstract}
Abstrak
Tujuan penelitian ini menganalisis hasil pelatihan yang difokuskan pada kepuasan alumni diklat terhadap pelayanan kediklatan di Pusdiklat Tenaga Teknis Pendidikan dan Keagamaan Kementerian Agama. Penelitian ini merupakan penelitian survei pada stakeholder Pusdiklat di Provinsi Sumatra Utara, Jawa Tengah, D.I. Yogyakarta dan Sulawesi Selatan dengan sampel sebanyak 50 orang yang diambil dengan teknik purposive random sampling. Instrumennya meliputi angket, pedoman wawancara dan ceklis dokumen. Analisis datanya dengan cara editing, tabulasi, dan analisis IKM serta interpretasi. Hasil penelitian menunjukkan indeks kepuasan alumni diklat terhadap pelayanan kediklatan pada kategori mutu pelayanan perunsur yaitu: 1) Unsur Persyaratan mendapatkan nilai 84 (kategori B/Baik); 2) Unsur sistem, mekanisme, dan prosedur mendapatkan nilai 87,5 (kategori B/Baik); 3) Unsur waktu penyelesaian mendapatkan nilai 86 (kategori B/Baik); 4) Unsur biaya/tarif mendapatkan nilai 94,625 (kategori A/Sangat Baik); 5) Unsur produk spesifikasi jenis pelayanan mendapatkan nilai 85 (kategori B/Baik); 6) Unsur kompetensi pelaksana mendapatkan nilai 88,063 (kategori B/Baik); 7) Unsur perilaku pelaksana mendapatkan nilai 88,5 (kategori A/Sangat Baik); 8) Unsur penanganan pengaduan, saran dan masukan mendapatkan nilai 77,5 (kategori B/Baik); dan 9) Unsur sarana dan prasarana mendapatkan nilai 83,929 (kategori B/Baik). Hasil nilai rata-rata konversi indeks tersebut adalah 85,26 sehingga kinerja Pusdiklat berdasarkan indeks kategori mutu pelayanan berada pada kategori "B" atau "BAIK".
\end{abstract}

Kata Kunci: Evaluasi Hasil Pelatihan, Kepuasan Alumni Diklat, Pelayanan Kediklatan

\begin{abstract}
[THE EVALUATION OF TRAINING RESULTS IN THE EDUCATION AND RELIGIOUS TECHNICAL TRAINING CENTER OF THE MINISTRY OF RELIGION]. The purpose of this study is to analyze the training results which are focused on the satisfaction of training alumni with education services in the Education and Religious Technical Training Center of the Ministry of Religion. This research is survey research to stakeholders in the Province of North Sumatra, Central Java, D.I. Yogyakarta and South Sulawesi with sampling were done with a purposive random sampling technique with a total of 50 people. The instruments used are questionnaires, interview guidelines, and document checklist. While the data analysis is done by editing, tabulating, and IKM analyzing as well as interpretations. The results of this study indicate that in the alumni satisfaction index of education and training services at that the quality category of service elements, namely: 1) Requirement Elements get 84 (B/Good category); 2) System, mechanism, and procedure elements get 87,5 (B/Good category); 3) The completion time element gets 86 (B/Good category); 4) The cost/tariff element gets 94,625 (category A/Very Good); 5) The product element specification type of service gets 85 (category $B / G o o d) ; 6$ ) The element of implementing competency gets 88,063 (category B/Good); 7) The element of implementing behavior gets 88.5 (category A/Nery Good); 8) The element of complaint handling, suggestions, and input get 77.5 (category B/Good); and 9) The elements of facilities and infrastructure get 83,929 (category $B / G o o d)$. The results of the average conversion value obtained results of 85.26 which based on the index is in the "B" or "GOOD" category.
\end{abstract}

Keywords: The Evaluation of Training Results, Training Alumni Satisfaction Index, Training Services

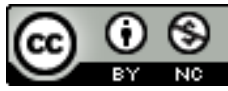

This work is licensed under a Creative Commons Attribution-NonCommercial 4.0 International Licens 


\section{PENDAHULUAN}

P

elayanan publik merupakan kegiatan atau rangkaian kegiatan dalam rangka pemenuhan kebutuhan pelayanan sesuai dengan peraturan perundang-undangan bagi setiap warga negara dan penduduk atas barang, jasa, dan/atau pelayanan administratif yang disediakan oleh penyelenggara pelayanan publik (UU No 25 , 2009 tentang Pelayanan Publik Pasal 1). Sebagai bagian dari pemerintah, Pusat Pendidikan dan Pelatihan Tenaga Teknis Pendidikan dan Keagamaan merupakan instansi di bawah Kementerian Agama mempunyai tugas melaksanakan penyusunan kebijakan teknis dan melaksanakan pelayanan publik dalam bentuk penyelenggaraan pendidikan dan pelatihan serta pengembangan tenaga teknis pendidikan dan keagamaan sesuai dengan ketentuan peraturan perundang-undangan (PMA No 75: 2015).

Berdasarkan beberapa penelitian yang dilakukan kalangan akademisi dan birokrat tentang pelayanan publik di Indonesia, ternyata kondisinya masih seringkali "dianggap" belum baik dan memuaskan. Hal ini ditunjukkan dari kesimpulan yang dibuat oleh Dwiyanto \& Kusumasari (2003:102) dalam GDS (Governance and Decentralization) 2002 pada 20 propinsi di Indonesia tentang kinerja pelayanan publik menyebutkan “... secara umum praktek penyelenggaraan pelayanan publik masih jauh dari prinsip-prinsip tata pemerintahan yang baik." Hal ini dikuatkan oleh temuan Ombudsman dalam Purnamasari (2017: 1) yang pada tahun 2015 dan 2016 mengadakan Penilaian Kepatuhan Standar Pelayanan Publik Kementerian/Lembaga. Penelitian ini menunjukkan bahwa Kementerian Agama pada tahun 2015 mendapatkan nilai 51,95 yang berada pada zona Merah dan pada tahun 2016 mendapatkan nilai 65,9 atau berada pada zona kuning. Meskipun terjadi peningkatan, tetapi masih belum menggembirakan karena masih berada pada zona kuning.

Sementara itu, dalam penelitian yang dilakukan oleh Sujarwo (2008:154-157) menunjukkan bahwa evaluasi kinerja penyelenggaraan Diklat PIM IV pada Balai Diklat Keagamaan Semarang menunjukkan bahwa status kinerja input (pelayan) adalah kurang. Status kinerja proses baik. Sedang status kinerja output (kinerja dan perubahan perilaku) adalah sedang. Kurangnya kinerja inputs disebabkan oleh rendahnya komitmen terhadap penyediaan faktor sumber pelayanan. Aspek pelayanan akademik yang masih berkinerja rendah semua berada pada indikator inputs tersebar pada unsur-unsur hardware dan software khususnya pada aspek kualifikasi peserta, penyediaan kelas, dan seleksi peserta. Akhirnya dapat dikemukakan bahwa faktor pendukung layanan akademik baik hardware maupun software masih perlu pembenahan yang memadai. Perubahan pola pikir dan pola kerja sumber daya aparatur tidak selalu berjalan sejajar dengan sikap dan perilaku kerja. Untuk mengoptimalkan peningkatan kompetensi alumni diklat, agaknya pembinaan langsung oleh atasan secara berkelanjutan menjadi sangat penting.

Sedangkan dalam Hanum Farida (2018: 191) dalam kajiannya tentang evaluasi penyelenggaraan diklat di Kementerian Agama menunjukkan bahwa secara umum komponen input program diklat dengan pemenuhan nilai sebesar 77,1 dengan kategori cukup. Pada komponen input penyelenggaraan diklat khususnya aspek kepesertaan, widyaiswara, kepanitiaan, akomodasi, kurikulum, konsumsi, sarana hanya bernilai cukup, namun aspek pemenuhan anggaran masih berkatagori kurang. Adapun komponen output menunjukkan nilai 73,5 katagori kurang. Hasil evaluasi memperlihatkan setelah peserta diklat mengikuti diklat, khusus aspek penggunaan alat peraga, penggunaan sumber belajar dan penggunaan metode pembelajaran, serta strategi pembelajaran harus lebih ditingkatkan karena mendapat katagori kurang. Selanjutnya hasil evaluasi secara umum pada komponen proses dikatagorikan cukup dengan pemenuhan nilai sebesar 82,2.

Pemberian pelayanan publik perlu diukur untuk melihat ketercapaian kepuasan pelayanan. Kepuasan pelayanan adalah hasil pendapat dan penilaian masyarakat terhadap kinerja pelayanan yang diberikan oleh aparatur 
penyelenggara pelayanan publik (Permenpan No 25: 2004 Pasal 1). Indeks Kepuasan Masyarakat merupakan acuan bagi unit pelayanan instansi pemerintah, yang dalam penelitian ini adalah Pusat Pendidikan dan Pelatihan Tenaga Teknis Pendidikan dan Keagamaan Badan Litbang dan Diklat Kementerian Agama RI. Indeks ini digunakan untuk mengetahui kinerja organisasi. Bagi masyarakat yang dalam hal ini adalah peserta dan alumni diklat. Indeks Kepuasan Masyarakat dapat digunakan sebagai gambaran tentang kinerja pelayanan unit yang bersangkutan.

Regulasi yang dikeluarkan oleh Kementerian Pendayagunaan Aparatur Negara Nomor 25 Tahun 2004 menyebutkan bahwa: 1) Pelayanan kepada masyarakat oleh aparatur pemerintah perlu terus ditingkatkan, sehingga mencapai kualitas yang diharapkan; 2) Untuk mengetahui kinerja pelayanan aparatur pemerintah kepada masyarakat, perlu dilakukan penilaian atas pendapat masyarakat terhadap pelayanan, melalui penyusunan indeks kepuasan masyarakat. Selanjutnya berdasarkan Permenpan RB. No 14 Tahun 2017, penyelenggara pelayanan publik termasuk Pusat Pendidikan dan Pelatihan Tenaga Teknis Pendidikan dan Keagamaan wajib melakukan survei kepuasan masyarakat secara berkala minimal 1 (satu) kali setahun dan survei dilakukan untuk memperoleh indeks kepuasan masyarakat yang dalam hal ini adalah peserta serta alumni diklat.

Tujuan pelayanan publik pada dasarnya adalah memuaskan masyarakat. Untuk mencapai kepuasan itu dituntut kualitas pelayanan publik yang tercermin dari Standar Kepuasan Masyarakat yang unsur-unsurnya meliputi:

1. Persyaratan; adalah syarat yang harus dipenuhi dalam pengurusan suatu jenis pelayanan, baik persyaratan teknis maupun administratif.

2. Sistem, Mekanisme, dan Prosedur; adalah tata cara pelayanan yang dibakukan bagi pemberi dan penerima pelayanan, termasuk pengaduan.

3. Waktu Penyelesaian; adalah jangka waktu yang diperlukan untuk menyelesaikan seluruh proses pelayanan dari setiap jenis pelayanan.
4. Biaya/Tarif; adalah ongkos yang dikenakan kepada penerima layanan dalam mengurus dan/atau memperoleh pelayanan dari penyelenggara yang besarnya ditetapkan berdasarkan kesepakatan antara penyelenggara dan masyarakat.

5. Produk Spesifikasi Jenis Pelayanan; adalah hasil pelayanan yang diberikan dan diterima sesuai dengan ketentuan yang telah ditetapkan. Produk pelayanan ini merupakan hasil dari setiap spesifikasi jenis pelayanan.

6. Kompetensi Pelaksana; adalah kemampuan yang harus dimiliki oleh pelaksana meliputi pengetahuan, keahlian, keterampilan, dan pengalaman.

7. Perilaku Pelaksana; adalah sikap petugas dalam memberikan pelayanan.

8. Penanganan Pengaduan, Saran dan Masukan; adalah tata cara pelaksanaan penanganan pengaduan dan tindak lanjut.

9. Sarana dan prasarana; Sarana adalah segala sesuatu yang dapat dipakai sebagai alat dalam mencapai maksud dan tujuan. Prasarana adalah segala sesuatu yang merupakan penunjang utama terselenggaranya suatu proses (usaha, pembangunan, proyek). Sarana digunakan untuk benda yang bergerak (komputer, mesin) dan prasarana untuk benda yang tidak bergerak (gedung). (Permenpan RB. No. 14 Tahun 2017).

Oleh karena itu, peneliti memandang perlu mengadakan penelitian untuk mengukur indeks kepuasan alumni diklat terhadap pelayanan kediklatan di Pusat Pendidikan dan Pelatihan Tenaga Teknis Pendidikan dan Keagamaan. Hal ini dimaksudkan untuk mengetahui tingkat kinerja unit pelayanan secara berkala sebagai bahan untuk menetapkan kebijakan dalam rangka peningkatan kualitas pelayanan publik selanjutnya.

Berdasarkan uraian di atas, dalam penelitian ini diangkat permasalahan tentang: "Bagaimana indeks kepuasan alumni diklat terhadap pelayanan kediklatan di Pusdiklat Tenaga Teknis Pendidikan dan Keagamaan?"

Penelitian ini memiliki tujuan untuk mengetahui indeks kepuasan alumni diklat terhadap pelayanan kediklatan di Pusdiklat Tenaga Teknis Pendidikan dan Keagamaan yang 
meliputi: 1) Persyaratan, 2) Sistem, Mekanisme, dan Prosedur, 3) Waktu Penyelesaian, 4) Biaya/Tarif, 5) Produk Spesifikasi Jenis Pelayanan, 6) Kompetensi Pelaksana, 7) Perilaku Pelaksana, 8) Penanganan Pengaduan, dan 9) Sarana dan prasarana.

\section{METODE PENELITIAN}

Penelitian ini menggunakan pendekatan kuantitatif sebagai proses menemukan pengetahuan yang menggunakan data berupa angka sebagai alat menganalisis keterangan mengenai apa yang ingin diketahui. Sedangkan berdasarkan metodenya, penelitian ini merupakan penelitian survei.

Populasi dalam penelitian ini adalah seluruh alumni peserta diklat yang telah mengikuti diklat di Pusdiklat Tenaga Teknis Pendidikan dan Kegamaan Kementerian Agama yang berasal dari Provinsi Sumatra Utara, Jawa Tengah, D.I. Yogyakarta dan Sulawesi Selatan pada periode tahun 2018. Dengan mempertimbangkan keterbatasan waktu, biaya, dan tenaga untuk meneliti suatu populasi menyebabkan perlunya dilakukan penentuan sampel. Penelitian ini mengambil sampel dengan teknik purposive random sampling berdasarkan pertimbangan daerah yang terdekat dengan peneliti dengan tetap mempertimbangkan keterwakilan yang meliputi alumni diklat tahun 2018 yang berasal dari Provinsi Sumatra Utara, Jawa Tengah, dan Sulawesi Selatan. Jumlah sampel dalam penelitian ini sebanyak 50 orang.

Penggalian data yang digunakan dalam penelitian ini adalah melalui angket, wawancara, dan studi dokumentasi. Instrumen penelitian yang digunakan adalah: 1) Kuesioner, yang disusun berdasarkan indikator yang telah ditetapkan dan merupakan data primer dalam penelitian ini, 2) Pedoman wawancara, wawancara diberikan kepada para alumni diklat yang dilakukan untuk memperkuat data yang diperoleh dari hasil angket, 3) Ceklis dokumen, antara lain laporan penyelenggaraan diklat, evaluasi penyelenggaraan diklat, dan data-data tentang Pusdiklat Tenaga Teknis Pendidikan dan Kegamaan Kementerian Agama. Instrumen- instrumen ini secara kolaboratif digunakan untuk mengetahui tingkat kualitas pelayanan kediklatan di Pusdiklat Tenaga Teknis Pendidikan dan Keagamaan.

Teknik analisis data dilakukan dengan menggunakan nilai Indeks Kepuasan Masyarakat (IKM) yang dihitung dengan menggunakan nilai rata-rata tertimbang masing-masing unsur pelayanan. Pengelolaan data penelitian ditempuh dengan cara : 1) editig, 2) tabulasi, dan 3) Analisis IKM dan Interpretasi.

\section{TEMUAN DAN PEMBAHASAN}

\section{Temuan}

a. Persyaratan

Persyaratan merupakan syarat yang harus dipenuhi dalam pengurusan suatu jenis pelayanan, baik persyaratan teknis maupun administratif. Untuk mengetahui jawaban responden terhadap aspek ini selengkapnya dapat dilihat pada tabel 1 di bawah ini :

Tabel 1. Persyaratan

\begin{tabular}{ccc}
\hline Kategori Jawaban & \multicolumn{2}{c}{ Persyaratan } \\
\cline { 2 - 3 } & 1 & 2 \\
\hline Sangat Baik & 23 & 21 \\
\hline Baik & 23 & 25 \\
\hline Kurang Baik & 4 & 4 \\
\hline Tidak Baik & 0 & 0
\end{tabular}

Sumber data : item kuesioner no 1 dan 2

b. Sistem, mekanisme dan prosedur

Unsur ini mengandung arti sebagai tata cara pelayanan yang dibakukan bagi pemberi dan penerima pelayanan termasuk pengaduan. Pada unsur ini, terdapat 5 pernyataan/pertanyaan yanng dikemukakan kepada responden, dengan jawaban yang dapat dilihat pada tabel 2 berikut ini:

Tabel 2. Sistem, mekanisme dan prosedur

\begin{tabular}{cccccc} 
Kategori & \multicolumn{5}{c}{ Sistem, Mekanisme dan Prosedur } \\
\cline { 2 - 6 } Jawaban & 3 & 4 & 5 & 6 & 7 \\
\hline Sangat Baik & 25 & 36 & 30 & 27 & 23 \\
\hline & & & & & \\
\hline Baik & 25 & 13 & 16 & 20 & 20 \\
\hline Kurang Baik & 0 & 1 & 4 & 3 & 6 \\
\hline Tidak Baik & 0 & 0 & 0 & 0 & 1 \\
\hline
\end{tabular}


Sumber data : item kuesioner no 3 s.d. 7

\section{c. Waktu penyelesaian}

Unsur ini merupakan deskripsi terhadap jangka waktu yang diperlukan untuk menyelesaikan seluruh proses pelayanan dari setiap jenis pelayanan, dengan ajwaban yang dapat dilihat pada tabel 3 berikut ini:

Tabel 3. Waktu penyelesaian

\begin{tabular}{ccccc}
\hline Kategori Jawaban & \multicolumn{4}{c}{ Waktu Penyelesaian } \\
\cline { 2 - 5 } & 8 & 9 & 10 & 11 \\
\hline Sangat Baik & 22 & 25 & 26 & 25 \\
\hline Baik & 28 & 19 & 21 & 24 \\
\hline Kurang Baik & 0 & 6 & 3 & 1 \\
\hline Tidak Baik & 0 & 0 & 0 & 0
\end{tabular}

Sumber data : item kuesioner no 8 s.d. 11

\section{d. Biaya}

Biaya merupakan ongkos yang dikenakan kepada penerima layanan dalam mengurus dan/atau memperoleh pelayanan dari penyelenggara yang besarnya ditetapkan berdasarkan kesepakatan antara penyelenggara dan masyarakat. Pada unsur ini, jawaban responden dapat dilihat pada tabel 4 berikut:

Tabel 4. Biaya

\begin{tabular}{ccccc}
\hline Kategori Jawaban & \multicolumn{4}{c}{ Biaya } \\
\cline { 2 - 5 } & 12 & 13 & 14 & 15 \\
\hline Sangat Baik & 44 & 39 & 42 & 36 \\
\hline Baik & 6 & 10 & 8 & 11 \\
\hline Kurang Baik & 0 & 1 & 0 & 3 \\
\hline Tidak Baik & 0 & 0 & 0 & 0
\end{tabular}

Sumber data : item kuesioner no 12 s.d. 15

e. Produk spesifikasi jenis pelayanan

Unsur ini dimaksudkan sebagai hasil pelayanan yang diberikan dan diterima sesuai dengan ketentuan yang telah ditetapkan. Produk pelayanan ini merupakan hasil dari setiap spesifikasi jenis pelayanan. Pada unsur ini, jawaban responden dapat dilihat pada tabel 5 berikut:

Tabel 5. Produk spesifikasi jenis pelayanan

\begin{tabular}{cccc}
\hline Kategori Jawaban & \multicolumn{3}{c}{$\begin{array}{c}\text { Produk Spesifikasi } \\
\text { Jenis Pelayanan }\end{array}$} \\
\cline { 2 - 4 } & 16 & 17 & 18 \\
\hline Sangat Baik & 27 & 19 & 23 \\
\hline Baik & 22 & 27 & 24 \\
\hline Kurang Baik & 0 & 4 & 3 \\
\hline Tidak Baik & 1 & 0 & 0 \\
\hline
\end{tabular}

Sumber data : item kuesioner no $16,17,18$

f. Kompetensi pelaksana

Kompetensi Pelaksana merupakan kemampuan yang harus dimiliki oleh pelaksana meliputi pengetahuan, keahlian, keterampilan, dan pengalaman. Pada unsur ini, jawaban responden dapat dilihat pada tabel 6 berikut:

Tabel 6. Kompetensi pelaksana

\begin{tabular}{ccccccccc}
\hline $\begin{array}{c}\text { Kategori } \\
\text { Jawaban }\end{array}$ & \multicolumn{7}{c}{ Kompetensi Pelaksana } \\
\cline { 2 - 9 } & 19 & 20 & 21 & 22 & 23 & 24 & 25 & 26 \\
\hline $\begin{array}{c}\text { Sangat } \\
\text { Baik }\end{array}$ & 30 & 36 & 28 & 23 & 22 & 24 & 26 & 27 \\
\hline Baik & 20 & 14 & 21 & 26 & 25 & 26 & 24 & 21 \\
\hline $\begin{array}{c}\text { Kurang } \\
\text { Baik }\end{array}$ & 0 & 0 & 1 & 1 & 3 & 0 & 0 & 2 \\
\hline $\begin{array}{c}\text { Tidak } \\
\text { Baik }\end{array}$ & 0 & 0 & 0 & 0 & 0 & 0 & 0 & 0 \\
\hline
\end{tabular}

Sumber data : item kuesioner no 19 s.d. 26

\section{g. Perilaku pelaksana}

Unsur ini dimaksudkan sebagai sikap petugas dalam memberikan pelayanan. Pada unsur ini, jawaban responden dapat dilihat pada tabel 7 berikut:

Tabel 7. Perilaku pelaksana

\begin{tabular}{ccccc} 
Kategori & \multicolumn{4}{c}{ Perilaku Pelaksana } \\
\cline { 2 - 5 } Jawaban & 27 & 28 & 29 & 30 \\
\hline Sangat Baik & 27 & 26 & 34 & 30 \\
\hline Baik & 20 & 20 & 15 & 19 \\
\hline Kurang Baik & 3 & 4 & 1 & 1 \\
\hline Tidak Baik & 0 & 0 & 0 & 0
\end{tabular}

Sumber data : item kuesioner no 27 s.d. 30

h. Penanganan pengaduan, saran dan masukan

Penanganan pengaduan, saran dan masukan adalah tata cara pelaksanaan penanganan pengaduan dan tindak lanjut. Pada unsur ini dapat dilihat jawaban responden pada tabel 8 berikut ini:

Tabel 8. Penanganan pengaduan, saran dan masukan

\begin{tabular}{cccc}
\hline Kategori Jawaban & \multicolumn{3}{c}{$\begin{array}{c}\text { Penanganan } \\
\text { Pengaduan, Saran dan } \\
\text { Masukan }\end{array}$} \\
\cline { 2 - 4 } & 31 & 32 & 33 \\
\hline Sangat Baik & 14 & 12 & 15 \\
\hline Baik & 27 & 27 & 29 \\
\hline Kurang Baik & 9 & 11 & 6 \\
\hline Tidak Baik & 0 & 0 & 0 \\
\hline
\end{tabular}


Sumber data : item kuesioner 31,32, 33

\section{i. Sarana dan prasarana}

Sarana merupakan segala sesuatu yang dapat dipakai sebagai alat dalam mencapai maksud dan tujuan. Prasarana adalah segala sesuatu yang merupakan penunjang utama terselenggaranya suatu proses. Sarana digunakan untuk benda yang bergerak (komputer, mesin) dan prasarana untuk benda yang tidak bergerak (gedung). Pada unsur ini, jawaban responden dapat dilihat pada tabel 9 berikut.

Tabel 9. Sarana prasarana

\begin{tabular}{cccccccc}
\hline Kategori & \multicolumn{7}{c}{ Sarana dan Prasarana } \\
\cline { 2 - 9 } Jawaban & 34 & 35 & 36 & 37 & 38 & 39 & 40 \\
\hline $\begin{array}{c}\text { Sangat } \\
\text { Baik }\end{array}$ & 25 & 24 & 21 & 15 & 31 & 24 & 8 \\
\hline Baik & 24 & 24 & 24 & 33 & 16 & 24 & 35 \\
\hline $\begin{array}{c}\text { Kurang } \\
\text { Baik }\end{array}$ & 1 & 2 & 5 & 2 & 3 & 2 & 6 \\
\hline $\begin{array}{c}\text { Tidak } \\
\text { Baik }\end{array}$ & 0 & 0 & 0 & 0 & 0 & 0 & 1 \\
\hline
\end{tabular}

Sumber data : item kuesioner no 34 s.d. 40

\section{Pembahasan}

a. Persyaratan

Pertanyaan 1 tentang informasi tentang kegiatan diklat diberikan sekitar 2 minggu sebelum diklat dilaksanakan dan pernyataan 2 tentang rentang waktu penerimaan informasi diklat, sehingga peserta diklat dapat memiliki waktu yang cukup untuk mempersiapkan diri mengikuti diklat masih ada $8 \%$ yang menyatakan kurang baik. Hal ini dikarenakan alur penyampaian surat yang terlalu panjang dari Pudiklat ke Kantor Wilayah Provinsi baru kemudian ke Kantor kementerian agama kab/kota dan untuk selanjutnya ke peserta diklat. Untuk mengetahui jawaban responden terhadap aspek ini selengkapnya dapat dilihat pada grafik 1 di bawah ini :

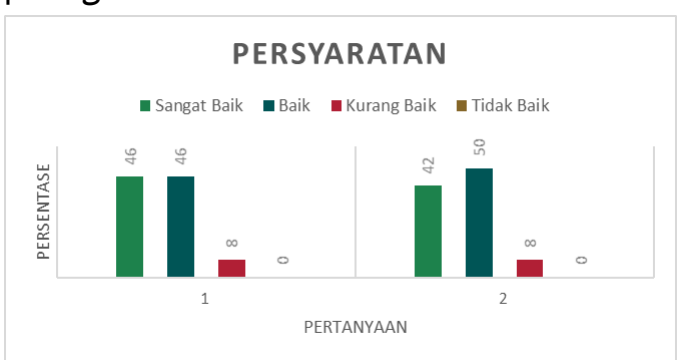

Grafik 1. Persyaratan b. Sistem, mekanisme dan prosedur

Unsur ini menekankan pada pertanyaan 3 tentang aspek proses registrasi yang jelas, pertanyaan 4 tentang jenis diklat yang diikuti sudah sesuai dengan kebutuhan, pertanyaan 5 tentang kejelasan jadwal pelaksanaan diklat dan peraturan diklat, pertanyaan 6 tentang informasi yang jelas mengenai fasilitas yang dapat digunakan oleh peserta diklat, dan pertanyaan 7 tentang penanganan keluhan peserta diklat oleh panitia dan widyaiswara. Penanganan keluhan peserta pada pernyataan 7 masih ada yang menyatakan kurang baik sebanyak $12 \%$. Hal ini disebabkan belum adanya hotline service. Untuk mengetahui jawaban responden terhadap aspek ini selengkapnya dapat dilihat pada grafik 2 berikut:

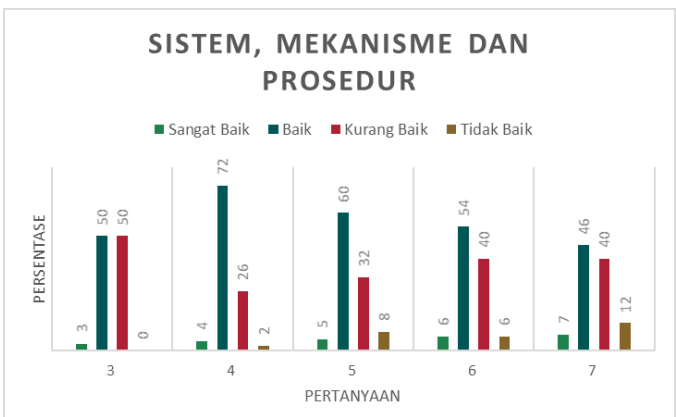

Grafik 2. Sistem, mekanisme, dan prosedur

c. Waktu penyelesaian

Pertanyaan no 9 tentang waktu pelaksanaan diklat yang diikuti sesuai dengan jadwal yang telah diberikan masih ada yang meyatakan kurang baik $12 \%$. Pelaksananan beberapa mata diklat terjadi perubahan jadwal tidak sesuai dengan perencanaan awal. Hal ini dikarenakan ada pergantian widyaiswara dan penyelesaian waktu pembelajaran lebih cepat selesai daripada jadwal yang telah ditentukan. Selain itu pelaksanaan diklat terlalu lama karena kompetensi awal peserta diklat yang kurang sehingga tidak dapat mengikuti pembelajaran dengan baik dan kegiatan diklat terasa lama. Untuk mengetahui jawaban responden terhadap aspek ini selengkapnya dapat dilihat pada grafik 3 berikut: 


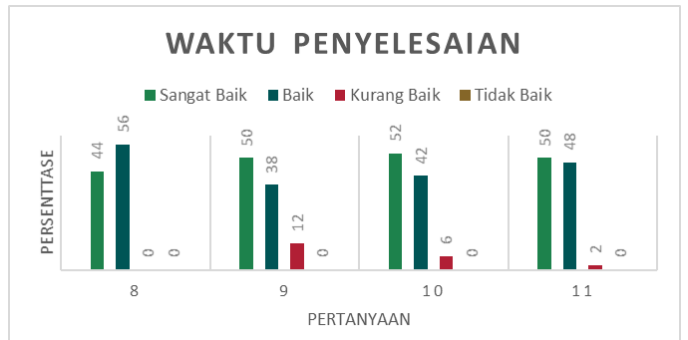

Grafik 3. Waktu penyelesaian

\section{d. Biaya}

Pada aspek tidak dipungut biayanya pada aspek pelayanan kesehatan yang diberikan oleh panitia diklat pada pertanyaan ke-15 masih terdapat 6 persen responden yang menyatakan Kurang Baik. Kondisi ini disebabkan oleh ada beberapa obat yang tidak tersedia di pelayanan kesehatan dan ketika peserta diklat mengalami rawat inap diperlukan pembiayaan secara mandiri. Untuk mengetahui jawaban responden terhadap aspek ini selengkapnya dapat dilihat pada grafik 4 berikut:

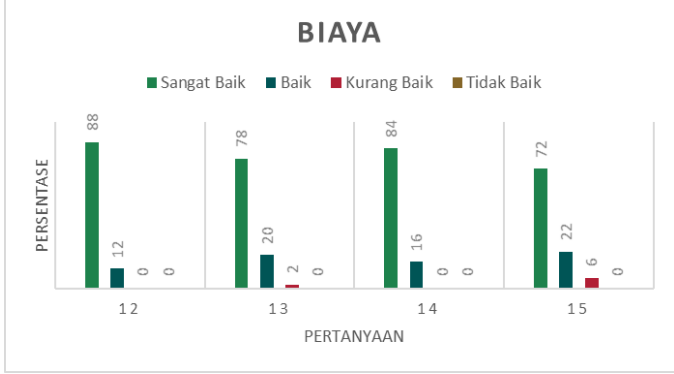

Grafik 4. Biaya

e. Produk spesifikasi jenis pelayanan

Unsur ini menitikberatkan pada aspek pelayanan akomodasi secara memadai, pelayanan konsumsi secara bervariasi, bersih, dan bergizi, dan pelayanan kesehatan dengan baik ketika mengalami masalah kesehatan. Pada pertanyaan 17 tentang pelayanan konsumsi masih terdapat 8 persen responden yang menyatakan kurang baik. Alumni diklat menyatakan variasi makanan yang kurang, jumlah sayuran serta buah yang kurang mencukupi dan terkadang jumlahnya juga kurang kalau terlambat makan dan harus masuk ke dapur untuk meminta tambahan konsumsi. Untuk mengetahui jawaban responden terhadap aspek ini selengkapnya dapat dilihat pada grafik 5 berikut:

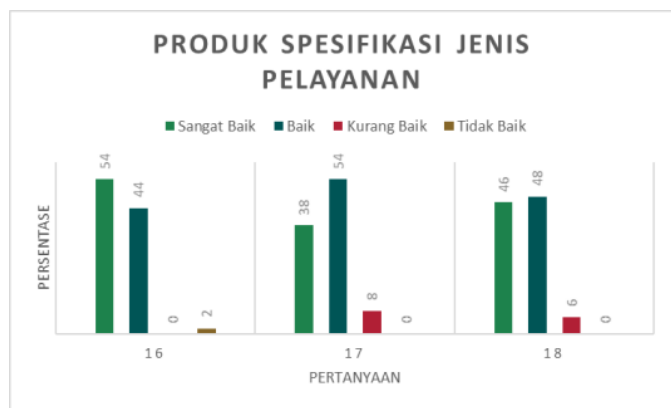

Grafik 5. Produk spesifikasi jenis pelayanan

\section{f. Kompetensi pelaksana}

Unsur ini menitikberatkan pada aspek: 1) pelayanan akademik secara professional dari widyaiswara, 2) Jaminan keamanan selama berada di lingkungan Pusdiklat, 3) Kenyamanan selama berada di ruang kelas terhadap pembelajaran yang dilakukan oleh widyaiswara, 4) Kenyamanan pelayanan dari petugas asrama selama di asrama, 5) Kenyamanan pelayanan dan dapat menikmati menu yang ada selama berada di ruang makan, 6) Widyaiswara memiliki kompetensi yang baik dalam penguasaan materi, penggunaan metode dan media pembelajaran, dan selalu memberikan. Pada pertanyaan 23 tentang kenyamanan pelayanan dan dapat menikmati menu yang ada selama berada di ruang makan $6 \%$ responden menyatakan kurang baik. Untuk mengetahui jawaban responden terhadap aspek ini selengkapnya dapat dilihat pada grafik 6 berikut:

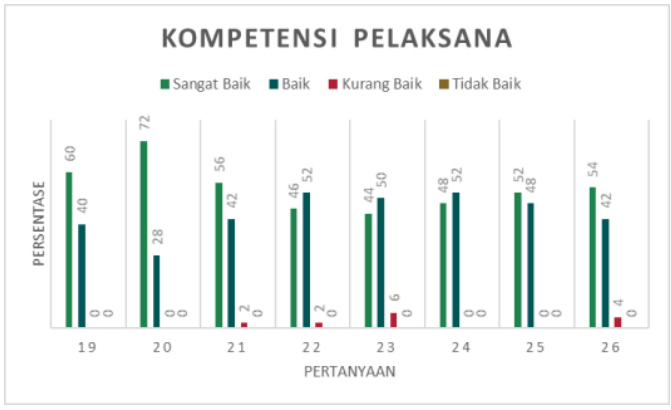

Grafik 6. Kompetensi pelaksana

\section{g. Perilaku pelaksana}

Pertanyaan 28 tentang keberadaan panitia diklat di ruang kelas untuk mendampingi widyaiswara melaksanakan pembukaan dan penutupan proses pembelajaran serta mempersiapkan semua yang dibutuhkan dalam kegiatan pembelajaran $8 \%$ menyatakan kurang baik karena panitia diklat hanya membuka proses pembelajaran dan jarang mendampingi 
widyaiswara di dalam kelas, sehingga ketika ada kebutuhan saat proses pembelajaran peserta diklat harus mencari panitia di ruang sekretariat. Untuk mengetahui jawaban responden terhadap aspek ini selengkapnya dapat dilihat pada grafik 7 berikut:

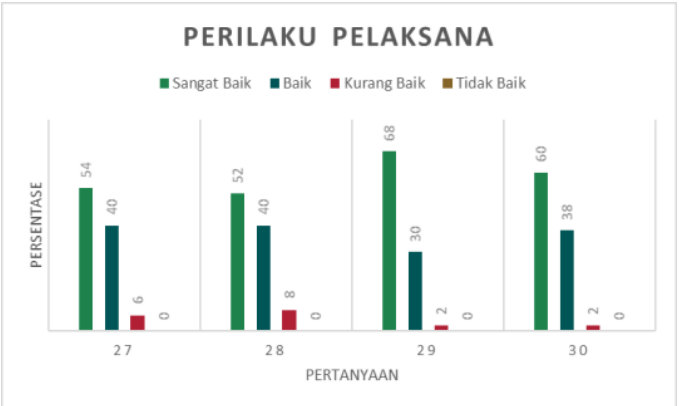

Grafik 7. Perilaku pelaksana

h. Penanganan pengaduan, saran dan masukan

Unsur ini menitikberatkan pada aspek kemudahan mendapatkan kotak saran di lingkungan Pusdiklat, ketersediaan pengaduan melalui telepon, online dan hotline service ketika mendapatkan masalah, dan keluhan dan pengaduan yang anda sampaikan, baik secara langsung maupun tidak langsung direspon secara cepat. Pertanyaan 32 tentang tersedia pengaduan melalui telepon, online dan hotline service jika mengalami gangguan ketidaknyamanan kapanpun di Pusdiklat 58\% meyatakan kurang baik. Untuk mengetahui jawaban responden terhadap aspek ini selengkapnya dapat dilihat pada grafik 8 berikut.

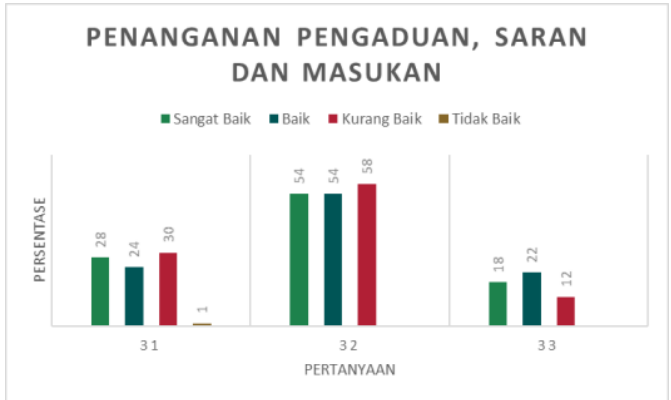

Grafik 8. Penanganan pengaduan, saran dan masukan

i. Sarana dan prasarana

Sarana digunakan untuk benda yang bergerak (komputer, mesin) dan prasarana untuk benda yang tidak bergerak (gedung).
Unsur ini menekankan pada aspek fasilitas yang ada dalam ruang kelas, asrama, ruang sekretariat, kamar mandi dan WC, tempat ibadah, ruang makan, dan perpustakaan. $10 \%$ responden menyatakan kurang baik pada pertanyaan 36 tentang ketersediaan ruang sekretariat yang representative Jika membutuhkan komunikasi dengan panitia. Pada pertanyaa 40 tentang ketersediaan literatur dan bacaan secara lengkap di perpustakaan masih terdapat $12 \%$ menyatakan kurang baik. Untuk mengetahui jawaban responden terhadap aspek ini selengkapnya dapat dilihat pada grafik 9 berikut.

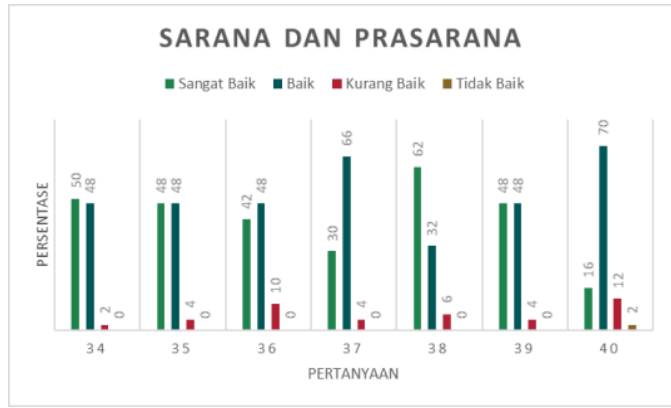

Grafik 9. Sarana prasarana

j. Indeks Kepuasan

Untuk mengetahui gambaran kepuasan alumni diklat terhadap pelayanan kediklatan di Pusdiklat Tenaga Teknis Pendidikan dan Keagamaan Kementerian Agama, akan diuraikan masing-masing pada indikatorindikator yang telah ditetapkan terlebih dahulu. Berdasarkan pengukuran terhadap 9 unsur (U) dalam pelayanan kediklatan, diperoleh perhitungan Indeks Kepuasan Masyarakat (IKM) yang dalam hal ini adalah para alumni diklat di Pusdiklat Tenaga Teknis Pendidikan dan Keagamaan. Berdasarkan hasil analisis diperoleh hasil Indeks Kepuasan Alumni Diklat Terhadap Pelayanan Kediklatan Perunsur Pelayanan pada tabel 10 sebagai berikut:

Tabel 10. Indeks Kepuasan Alumni Diklat Terhadap Pelayanan Kediklatan

\begin{tabular}{cccccc} 
N0 & $\begin{array}{c}\text { UNSUR } \\
\text { PELAYANAN }\end{array}$ & $\begin{array}{c}\text { NILAI } \\
\text { IKM }\end{array}$ & $\begin{array}{c}\text { NILAI } \\
\text { KONVER } \\
\text { SI IKM }\end{array}$ & $\begin{array}{c}\text { MUTU } \\
\text { PELAYA } \\
\text { NAN }\end{array}$ & $\begin{array}{c}\text { KINERJ } \\
\text { A }\end{array}$ \\
\hline 1 & Persyaratan & 3,36 & 84 & B & Baik \\
\hline 2 & $\begin{array}{l}\text { Sistem, } \\
\text { Mekanisme, }\end{array}$ & 3,5 & 87,5 & B & Baik \\
\hline
\end{tabular}




\begin{tabular}{|c|c|c|c|c|c|}
\hline & $\begin{array}{l}\text { dan } \\
\text { Prosedur }\end{array}$ & & & & \\
\hline 3 & $\begin{array}{l}\text { Waktu } \\
\text { Penyelesaia } \\
\text { n }\end{array}$ & 3,44 & 86 & $B$ & Baik \\
\hline 4 & Biaya/Tarif. & 3,78 & 94,6 & A & $\begin{array}{c}\text { Sang } \\
\text { at } \\
\text { Baik }\end{array}$ \\
\hline 5 & $\begin{array}{l}\text { Produk } \\
\text { Spesifikasi } \\
\text { Jenis } \\
\text { Pelayanan }\end{array}$ & 3,4 & 85 & $B$ & Baik \\
\hline 6 & $\begin{array}{l}\text { Kompetensi } \\
\text { Pelaksana }\end{array}$ & 3,52 & 88,01 & B & Baik \\
\hline 7 & $\begin{array}{l}\text { Perilaku } \\
\text { Pelaksana }\end{array}$ & 3,54 & 88,5 & A & $\begin{array}{c}\text { Sang } \\
\text { at } \\
\text { Baik }\end{array}$ \\
\hline 8 & $\begin{array}{l}\text { Penanganan } \\
\text { Pengaduan, } \\
\text { Saran dan } \\
\text { Masukan }\end{array}$ & 3,1 & 77,5 & $B$ & Baik \\
\hline 9 & $\begin{array}{l}\text { Sarana dan } \\
\text { Prasarana }\end{array}$ & 3,36 & 83,9 & $B$ & Baik \\
\hline \multicolumn{2}{|c|}{ Rata -rata } & 3,41 & 85,26 & B & Baik \\
\hline
\end{tabular}

Nilai IKM dari unsur pelayanan kediklatan menunjukkan penilaian alumni diklat terhadap unsur pelayanan tersebut. Pada tabel di atas menunjukkan bahwa nilai terbaik pelayanan kediklatan berada pada unsur Biaya/Tarif dan Perilaku Pelaksana yang berada pada kategori Sangat Baik. Sedangkan unsur terendah berasal pada unsur Penanganan Pengaduan, Saran dan Masukan yang berada pada nilai 77,5. Meskipun demikian, pada unsur ini tetap berada pada kategori Baik

Hasil nilai konversi IKM yang dalam hal ini adalah alumni diklat terhadap pelayanan kediklatan pada Pusdiklat Tenaga Teknis Pendidikan dan Keagamaan Kementerian Agama memperoleh hasil sebesar 85,26. Kinerja Pusdiklat Tenaga Teknis Pendidikan dan Keagamaan Kementerian Agama berdasarkan kategori mutu pelayanan berdasarkan indeks berada pada mutu pelayanan " $\mathrm{B}$ " dengan kategori "BAIK.

Kualitas pelayanan kediklatan perlu ditentukan berdasarkan dimensi yang ditetapkan regulasi dan relevan dengan kondisi kediklatan yang terus berkembang dinamis sehingga dapat memenuhi harapan stakeholder. Pelayanan dikatakan berkualitas apabila stakeholder menerima pelayanan sesuai atau melebihi harapan yang diinginkan.
Undang-Undang No. 25 Tahun 2009 tentang Pelayanan Publik menyebutkan dalam Pasal 1 ayat 7 bahwa standar pelayanan merupakan tolok ukur yang dipergunakan sebagai pedoman penyelenggaraan pelayanan dan acuan penilaian kualitas pelayanan sebagai kewajiban dan janji penyelenggara kepada masyarakat dalam rangka pelayanan yang berkualitas, cepat, mudah, terjangkau, dan terukur. Penyelenggaraan pelayanan publik termasuk dalam hal ini juga pelayanan kediklatan harus berasaskan kepentingan umum, kepastian, kepastian hukum, kesamaan hak, keseimbangan hak dan kewajiban, keprofesionalan, partisipatif, persamaan perlakuan/tidak diskriminatif, keterbukaan, akuntabilitas, fasilitas dan perlakuan khusus bagi kelompok rentan, ketepatan waktu, dan kecepatan, kemudahan, dan keterjangkauan. Asas-asas itu harus menjadi acuan para penyelenggara dalam melaksanakan pelayanan kediklatan yang optimal.

Di samping struktur kurikulum, peserta diklat, dan sarana serta prasarana kediklatan, terdapat dua unsur kediklatan yang memegang peranan sangat penting, yaitu aparatur yang terlibat dalam penyelenggaraan diklat yaitu widyaiswara dan penyelenggara (panitia diklat). Oleh karena itu, tuntutan kualitas penyelenggaraan diklat juga ditujukan pada peningkatan kualitas widyaiswara dan panitia diklat.

Widyaiswara merupakan tenaga fungsional yang mempunyai peranan yang sangat besar dalam pembentukan sikap mental dan kualitas intelektualitas peserta diklat. Tugas yang diemban oleh widyaiswara adalah memfasilitasi peserta diklat dalam meningkatkan pengetahuan dan keterampilannya. Akan tetapi, hal yang lebih penting adalah membentuk kepribadian peserta diklat melalui didikan yang dikomunikasikan, baik secara verbal maupun non-verbal. Widyaiswara tidak hanya dituntut menguasai materi, metode, dan teknik berkomunikasi, tetapi juga memiliki sikap dan kepribadian yang baik yang tergambar dalam proses pembelajaran. Kepribadian yang dimiliki widyaiswara harus mencerminkan kesederhanaan, menjunjung tinggi kedisiplinan, sportivitas, representatif, akomodatif, tidak diskriminatif, mampu 
mengkomunikasikan buah pikiran, menerapkan pendidikan dengan pendekatan andragogi, dan mampu mendayagunakan alat peraga dan alat bantu dengan baik.

Panitia diklat juga merupakan komponen yang penting dalam mendukung keberhasilan suatu diklat. Profesionalisme lembaga diklat sangat ditentukan oleh profesionalisme penyelenggaranya karena penyelenggara memiliki akses dan kontrol terhadap sumbersumber yang diperlukan untuk memperlancar penyelenggaraan diklat. Dalam manajemen kediklatan, panitia diklat bersama dengan widyaiswara merupakan pelaku utama yang terlibat dalam penyelenggaraan diklat. Panitia diklat berperan antara lain, mengatur seluruh pengelolaan proses latihan mulai dari persiapan sampai pelaporan. Panitia diklat mengatur persiapan tempat belajar, penjadwalan, kesiapan widyaiswara, kesiapan peralatan/ perlengkapan diklat, naskah materi pembelajaran. Panitia diklat juga mengatur kesiapan kesekretariatan, akomodasi dan konsumsi peserta diklat, mengatur sarana angkutan untuk keperluan praktek atau kegiatan di luar kampus. Panitia diklat juga memiliki tugas dan kewajiban untuk melayani, mengamati, dan menilai peserta diklat selama berada di lingkungan kampus.

Dalam konteks ini, selaras dengan prinsip pelayanan publik, Moenir (2005: 47) berpendapat bahwa pemerintah dalam memberikan pelayanan publik terbaik kepada publik, dapat dilakukan dengan cara: 1) Kemudahan dalam pengurusan kepentingan, 2) Mendapatkan pelayanan secara wajar, 3) Mendapatkan perlakuan yang sama tanpa pilih kasih, dan 4) Mendapatkan perlakuan yang jujur dan terus terang.

Sementara itu untuk meningkatkan kualitas pelayanan publik, Budiman (2004: 73) menyebutkan lima indikator pelayanan publik yang harus dimiliki, yaitu: 1) Reliability, yaitu pemberian pelayanan yang tepat dan benar, 2) Tangibles, yaitu penyediaan yang memadai sumber daya manusia dan sumber daya lainnya, 3) Responsiveness, yaitu keinginan melayani konsumen dengan cepat, dan 4) Assurance, yaitu tingkat perhatian terhadap etika dan moral dalam memberikan pelayanan.
Peningkatan kualitas pelayanan kediklatan perlu dilakukan tidak hanya melalui peningkatan kualitas sarana dan prasarana penyelenggaraan diklat, tetapi juga melalui pengembangan profesionalisme widyaiswara dan panitia diklat disertai dengan penciptaan sistem dan budaya kerja yang menjamin kebersamaan dan keteraturan kerja. Untuk mewujudkan hal tersebut, tentunya diperlukan proses, kesungguhan, dan sikap istiqamah dar semua unsur diklat sebagai tuntutan mutlak dalam pencapaian tujuan diklat.

\section{PENUTUP}

\section{Simpulan}

Berdasarkan uraian di atas, dapat dikemukakan beberapa poin sebagai kesimpulan, yaitu:

a. Hasil analisis indeks kepuasan alumni diklat terhadap pelayanan kediklatan menunjukkan bahwa kategori mutu pelayanan perunsur yaitu:

1) Unsur Persyaratan mendapatkan nilai 84 atau berada pada kategori B (Baik);

2) Unsur sistem, mekanisme, dan prosedur mendapatkan nilai 87,5 atau berada pada kategori B (Baik);

3) Unsur waktu penyelesaian mendapatkan nilai 86 atau berada pada kategori B (Baik);

4) Unsur biaya/tarif mendapatkan nilai 94,625 atau berada pada kategori A (Sangat Baik);

5) Unsur produk spesifikasi jenis pelayanan mendapatkan nilai 85 atau berada pada kategori B (Baik);

6) Unsur kompetensi pelaksana mendapatkan nilai 88,063 atau berada pada kategori B (Baik);

7) Unsur perilaku pelaksana mendapatkan nilai 88,5 atau berada pada kategori $A$ (Sangat Baik);

8) Unsur penanganan pengaduan, saran dan masukan mendapatkan nilai 77,5 atau berada pada kategori B (Baik);

9) Unsur sarana dan prasarana mendapatkan nilai sebesar 83,929 atau berada pada kategori B (Baik). 
b. Hasil nilai konversi IKM yang dalam hal ini adalah alumni diklat terhadap pelayanan kediklatan pada Pusdiklat Tenaga Teknis Pendidikan dan Keagamaan Kementerian Agama memperoleh hasil sebesar 85,26. Kinerja Pusdiklat Tenaga Teknis Pendidikan dan Keagamaan Kementerian Agama berdasarkan kategori mutu pelayanan berdasarkan indeks berada pada mutu pelayanan "B" dengan kategori "BAIK".

\section{Rekomendasi}

Penelitian ini memiliki implikasi dalam bentuk rekomendasi sebagai berikut:

a. Pusdiklat mensosialisasikan jadwal pelaksanaan kegiatan diklat dalam satu tahun lengkap dengan alokasi peserta setiap provinsi dan mengembangkan $e$ registrasion sehingga calon peserta diklat dapat melakukan pendaftaran secara online. Selanjutnya proses verifikasi ke Kantor Kementerian Agama Kabupaten/Kota untuk selanjutkan berkoordinasi dengan Kantor Wilayah Provinsi untuk menerbitan surat tugas;

b. Membuat Response Time Dudik (pengaduan diklat) berupa hotline service untuk melayani keluhan peserta diklat selama 24 jam;

c. Penambahan akomodasi peserta diklat berupa satu paket perlengkapan mandi (sabun mandi, sikat dan pasta gigi serta sandal);

d. Penggantian botol mineral dengan botol minum yang bisa diisi ulang dengan air gallon untuk mengurangi sampah plastik;

e. Peningkatan pelayanan konsumsi dalam hal variasi menu, kebersihan dan bernilai gizi sesuai dengan cara berkonsultasi dengan ahli gizi dalam hal pemilihan menu makanan. Menu makanan selama kegiatan diklat dapat dicamtumkan sehingga jika ada peserta yangtidak cocok dengan menu yang disediakan bisa mencari alternatif menu di luar kampus;

f. Panitia harus standby di ruangan kelas dengan membuat jadwal jaga panitia sehingga ketika ada keluhan di kelas langsung bisa ditangani; g. Pusdiklat diharapkan menggunakan aplikasi berbasis Android yang mampu menampung semua informasi tentang kegiatan kediklatan, antara lain: Program diklat, Registrasi, Jadwal Kegiatan, Panitia, Widyaiswara, Pengaduan, Evaluasi, dan Sertifikat yang bisa diakses secara langsing oleh Panitia;

H. Melakukan pengukuran Indeks Kepuasan Layanan setiap tahun dengan menyiapkan instrument di website. 


\section{DAFTAR PUSTAKA}

Dwiyanto, A., \& Kusumasari, B. (2003). Reformasi Pelayanan Publik: Apa yang Harus Dilakukan?

Hanum. Farida. (2018). The Evaluation Of Training And Education Program Administration In The Ministry of Religious Affairs. EDUKASI: Jurnal Penelitian Pendidikan 16(2), 191-203. Retrieved from http://creativecommons.org/licenses/by-sa/4.0/

Ibrahim, Amin. Teori dan Konsep Pelayanan Publik Serta. Implementasinya. Bandung: Mandar Maju, 2008.

Kepmenpan No 25 (2004). Pedoman Umum Penyusunan Indeks Kepuasan Masyarakat Unit Pelayanan Instansi Pemerintah Retrieved from https://www.atrbpn.go.id/Publikasi/Peraturan-Perundangan/PeraturanLain/keputusan-menteri-pendayagunaan-aparatur-negara-nomor-kep25mpan22004-609

Moenir, A.S. Manajemen Pelayanan Umum di Indonesia. Jakarta: Bumi Aksara, 2010.

Peraturan Menterin Agama RI. No 75 (2015). Penyelenggaraan Diklat Pegawai Kemenag

Peraturan Menteri Pendayagunaan Aparatur Negara dan Reformasi Birokrasi Republik Indonesia Nomor 14 Tahun 2017 tentang Pedoman Penyusunan Survei Kepuasan Masyarakat Unit Penyelenggara Pelayanan Publik

Peraturan Menteri Pendayagunaan Aparatur Negara dan Reformasi Birokrasi Republik Indonesia Nomor 17 Tahun 2017 tentang Pedoman Penilaian Kinerja Unit Penyelenggara Pelayanan Publik.

Purnamasari, D. (2017). Efektifkah Layanan Publik PNS? - Tirto.ID. Retrieved April 1, 2020, from https://tirto.id/efektifkah-layanan-publik-pns-cwlh

Rangkuti, Freddy. Measuring Costomer Satisfaction. Jakarta: PT Gramedia Pustaka Utama, 2002.

Ratminto, Atik Septi Winarsih. Manajemen Pelayanan. Jakarta: Pustaka Pelajar, 2005.

Sugiyono. (2012). Metode Penelitian Kuantitatif Kualitatif dan R\&D. Bandung: Alfabeta.

Sujarwo. (2008). Evaluasi Kinerja Penyelenggaraan Pendidikan dan Pelatihan Kepemimpinan Tingkat IV pada Balai Diklat Keagamaan Semarang. Tesis, 221.

Sinambela, Lijan Poltak, dkk. Reformasi Pelayanan Publik. Jakarta: Bumi Aksara, 2011.

Sitanggang, Yuliana Ria Uli, Peningkatan Kinerja Pelayanan pada Lembaga Pendidikan dan Pelatihan (Diklat). Jurnal. Diakses di http://pusdiklat.bps.go.id/files/lain-lain/Peningkatan_Kinerja_ Pelayanan Pusdiklat.pdf., 2017.Sugiyono. Metode Penelitian Kuantitatif Kualitatif dan R\&D. Bandung: Alfabeta, 2012.

Undang-Undang RI Nomor 5 tahun 2014, tentang Aparatur Sipil Negara.

UU No 25. (2009). UU Nomor 25 Tahun 2009 Tentang"Pelayanan Publik". UU Nomor 25 Tahun 2009 Tentang"Pelayanan Publik". 